\title{
The Secret Army of Drinkers
}

Of every-one hundred women who are drunk, it is probable that a larger number would commit disorderly acts, being of a more excitable temperament, and also because women when they take to evil courses are often more shameless than men? ${ }^{1}$

There was another group of drinkers in Victorian Britain for whom temperance and teetotalism held little weight. If working-class men can be defined as the 'great army' of drinkers then women can be regarded as the secret army, although as the quote above demonstrates, some were more secret about their drinking habits than others. The 1877 Select Committee of the House of Lords on Intemperance (1877 enquiry) investigated two main aspects of women's drinking: one was middle-class drinking linked to licensed grocers and the other was working-class drinking linked to vice and crime. The division in attitudes between public and private drinking was significant. There were many facts and figures presented regarding criminal drunkenness among poor women because they often drank publicly on the city streets and in pubs. Yet the private-drinking habits of higher-class women buying alcohol from grocers remained more elusive and often the evidence presented amounted to little more than conjecture. The standpoint of the investigation was that all women were, by their very nature, more susceptible to the effects of alcohol than men and were therefore worse drunks than men.

In the 1877 enquiry, the Chief Constable of Sheffield, John Jackson, stated that drunken arrests among women had increased from $15.7 \%$ https://doi.org/10.1007/978-3-319-92964-4_4 
in 1847 to $24.3 \%$ in $1876 . .^{2}$ When asked to account for this increase he stated that there were a higher proportion of women working in factories in Sheffield and he believed these women were adopting men's drinking habits. ${ }^{3}$ This idea of women 'mirroring' male behaviour was a common argument put forward by many witnesses and while it did not appear to excuse women's drinking behaviour, it did locate it within the boundaries of male control. The idea that women simply mimicked men was perhaps easier to comprehend than the alternative of women actively consuming alcohol for their own purposes. Jackson argued that lowerclass women more generally were more prone to drunkenness and he cited hawkers, peddlers, petty traders and factory workers as the worst drunken offenders. ${ }^{4}$ Some committee members and witnesses seemed to share the opinion that drunken women were more of a public nuisance than drunken men and were therefore more likely to be arrested. The minister for Liverpool Prison, Reverend James Nugent, stated that in 1876 there were 4212 male prisoners and 5098 female prisoners within the gaol. ${ }^{5}$ Moreover he stated that the majority of women were imprisoned for drink related crime and some were repeat offenders having been convicted fifty, sixty or seventy times. ${ }^{6} \mathrm{He}$ believed that the prison was overcrowded with women of Irish descent who lived and worked in and around the Liverpool docks making their living through prostitution. ${ }^{7}$ Nugent described these women as ruthless in their pursuit of sailors who would provide them with shelter, clothing and drink. ${ }^{8}$ The increase in drunken arrests among women in cities and large manufacturing towns was attributed mainly to prostitution and petty crime and often the Irish were singled out as the worst offenders.

John Bremner, a Manchester magistrate, presented statistics relating to the numbers of arrests for drunkenness among the Irish population. He stated that in 1876, the total number of drunken arrests among the Irish was 2466 and that 789 of these were women. ${ }^{9}$ Bremner did not provide any comparative figures for previous years but did state that in 1876 the total number of drunken arrests for all women was $2743 .{ }^{10}$ This meant that the overwhelming majority of drunken arrests were for non-Irish women. Yet this fact evaded scrutiny and instead the figures for drunken arrests among Irish women were set within the context of Bremner's views on the changing drinking habits of the Manchester working classes. He believed that a recent influx of Irish immigrants from Liverpool to Manchester to work in the cotton mills had encouraged the popularity and spread of dram shops and dancing saloons. Bremner 
argued that the pubs in Manchester had 'degenerated' from being houses of refreshment which served food and drink to 'simple dram shops' which encouraged female drunkenness. ${ }^{11}$

Many witnesses expressed the belief that women were worse drunks than men because they were more of a nuisance and more shameful. Yet it was not only witnesses who held this belief. One member of the 1877 committee, the Bishop of Carlisle commented 'I suppose the effect of liquor upon a woman is greater than upon a man; that they are more likely to be disorderly than a man would be on the same amount of liquor.' 12 This idea that women simply could not 'hold their drink' in the same way as men were put to witnesses such as general practitioners, police, prison officials and asylum doctors. Mr William Smith, Governor of Ripon Prison in Yorkshire, stated that in his experience women were prone to more frequent habits of intoxication than men. ${ }^{13} \mathrm{He}$ cited the example of a female prisoner who had been repeatedly convicted for drunkenness and had spent several years in and out of prison. The woman was released from prison and given a home and employment on the condition that she sign the pledge and give up drinking. The woman worked for a few weeks then she got drunk and left her job, claiming that she could not live on charity. ${ }^{14}$ In the 1872 Select Committee on Habitual Drunkards (1872 enquiry), Dr Alexander Peddie, an Edinburgh physician noted for his professional interest in treating inebriety, recounted his experience of treating women with dipsomania

I have had the most solemn assertions that not a drop of liquor has crossed their lips for many hours, when they could not have walked across the floor; that not a drop of liquor was within their power; when I would find bottles of liquor wrapped up in stockings and other articles of clothing ... and on a late occasion, in the case of a lady, after all means had failed in discovering where the drink came from, on making a strict personal examination, found a bottle of brandy concealed in the armpit, hung around the neck with an elastic cord so that she might help herself as she pleased. Next morning seeing that the drunkenness still continued, and that something more was to be got at, there was actually found a bottle of brandy tied in some way, round the loins, and placed between her thighs. ${ }^{15}$

Perhaps it was Peddie's intention to provide a shocking tale of drinking that transgressed the boundaries of 'decent' and 'respectable' femininity but the idea of alcohol as a temptation that some women simply could not resist was one of the reasons why the 1877 enquiry constantly 
returned to the question of women and licensed grocers. The 1860 Wine and Refreshment Houses Act had led to the expansion of the offlicense trade and consequently the numbers of licensed grocers selling wine, beer and spirits had increased. The 1860 Act marked Gladstone's attempts as Chancellor of the Exchequer, to overhaul the system of duties on alcohol. This involved lowering the duties on imported wine and allowing alcohol to be sold for consumption off the premises in a wider range of shops and restaurants. These measures were hoped to encourage the British population to consume wine instead of beer and spirits, which in turn was intended to promote more 'civilised' and moderate drinking habits. ${ }^{16}$ Allowing the sale of small quantities of wine and spirits in shops and restaurants meant that alcohol could be bought from places other than pubs. Consequently, women who did not or could not visit pubs were able to buy alcohol from an increased number of retail outlets.

Many witnesses were asked about an increase in drunkenness among women that could be directly attributed to the expansion of licensed grocers. The general consensus among witnesses seemed to be that it was mainly middle-class women who purchased alcohol from grocers and that women of the lower classes were more likely to buy alcohol from pubs. Obtaining alcohol from licensed grocers was regarded as perfectly acceptable if women were buying wine and spirits for household use in dining, cooking and entertaining. However, there were concerns that some women were purchasing alcohol for their own personal use and in the 1877 enquiry, the Rector of Wrexham, Reverend David Howell stated that he knew of several instances where respectable women were led to drinking through licensed grocers. He felt that licensed grocers made it easier for women to buy liquor because they could purchase it along with their groceries, thus escaping shame and detection by their husbands. ${ }^{17}$ Captain James Nicholls, the Chief Constable of Newcastle believed that women 'of a higher station' were inclined to purchase alcohol from grocers because they would be too ashamed to go to public houses and that grocer's licenses were directly responsible for an increase in drinking among middle and upper class women. However, when asked if he had any evidence to support his views, he stated that it was just a general opinion. ${ }^{18}$ Witnesses often resorted to vague conjecture when asked about the links between women's drinking and licensed grocers. However, some of the evidence given during The 1878 Grocers Licenses (Scotland) Commission provided more persuasive accounts of women's 
drinking. The evidence from this enquiry was widely reported in the Scottish and national newspapers, providing sensationalist accounts of women's drinking. One witness, Duncan McLaren an Edinburgh MP, read an extract from the medical journal The Lancet that reported on a meeting of the Brewster Sessions in West Riding. Brewster sessions were the annual meetings of licensing justices to deal with the granting, renewal, and transfer of licenses to sell intoxicating liquor. The report stated that there was evidence to suggest that women who visited licensed grocers to purchase groceries were tempted to procure a bottle of wine or spirits for their own private consumption. ${ }^{19}$ During 1877 The Lancet ran a series of articles relating to licensed grocers because a group of physicians, surgeons and general practitioners had signed a petition calling for parliament to look at the issue of secret drinking. In a statement published in The Lancet the group of 920 doctors claimed that

\begin{abstract}
We believe women, servants and children of respectable households, who could not, or would not, procure intoxicating drinks at public houses are encouraged to purchase and use these liquors by the opportunity offered when visiting grocers shops for other purposes. Female domestic servants are often enabled to obtain bottles of spirits, wine and beer at a small cost on credit, or as 'commission' on the household bills. This trade is wholly removed from police supervision and is a direct incentive to 'secret drinking' - a practice more injurious to the health and morals and social prosperity of the community than ordinary trade in intoxicating liquors. ${ }^{20}$
\end{abstract}

The 'evil of secret drinking' that the doctors outlined in their petition went beyond a purely medical matter because it was embroiled with ideas about respectable femininity. One witness from the Grocers Licenses (Scotland) Commission, Reverend William Turner of the Edinburgh City Mission, read a statement from one of his informers who worked for the Mission. The informer was acquainted with the daughter of a 'respectable' married woman who claimed that her mother was 'given to drink' and had purchased alcohol 'hundreds of times' from Edinburgh grocers that concealed the purchases by falsifying the customer accounts. ${ }^{21}$ The statement continued that father of the family, described as 'a hardworking and worthy man' had checked the grocer's account books to discover that the records had been falsified to conceal his wife's purchases of whisky. The conclusion was that the grocer and the 'foolish' wife had colluded in this deceit. ${ }^{22}$ The main dilemma facing 
the parliamentary enquiries and the doctors who signed the petition was deciding if licensed grocers actively encouraged, either by their very existence or in collusion with women, the practice of secret domestic drinking. This type of drinking not only challenged feminine ideals but more importantly, it defied patriarchal authority - in other words 'worthy' and 'hard working' men were being duped into paying for liquor by unscrupulous grocers and 'foolish' wives.

Yet not all the witnesses agreed that licensed grocers actively encouraged women to drink and some still felt that men largely kept women's drinking in check. One newspaper that reported on the Grocers Licenses (Scotland) Commission cited the testimony of Provost King of Rutherglen, a textile manufacturer who employed 250 women in his factory. King stated that he had no knowledge of wives drinking 'without the consent' of their husbands and therefore in this regard licensed grocers did not present any kind of temptation. ${ }^{23}$ However it seemed that not all women sought permission from their husbands to drink. The real issue with licensed grocers was that they enabled women to drink 'in secret' beyond the male gaze. In contrast, working-class women drank publicly under the glare of moral scrutiny.

This builds a picture of female drinking that ranged across social classes and occurred in both public and private settings. Although many witnesses believed alcohol presented a temptation to women, it could be argued that it also presented a means of resisting patriarchal authority. If the great army of male drinkers stood strong against temperance and sobriety, then perhaps the women's secret army made their own stand against patriarchy and feminine ideals through the consumption of alcohol. This fits with de Certeau's ideas of a consumer grid of resistance

Many everyday practices (talking, reading, moving about, shopping, cooking etc.) are tactical in character. And so are, more generally, many 'ways of operating': victories of the 'weak' over the 'strong' (whether the strength be that of powerful people or the violence of things or of an imposed order, etc.). ${ }^{24}$

Public drunkenness and secret drinking were constructed as deviant and immoral precisely because they were defiant acts that involved the agency of women as alcohol consumers. This agency held power and therefore it was difficult to grasp the concept that women could actively choose to buy and consume alcohol for their own purposes of intoxication. It was 
easier to locate women's drinking within the framework of patriarchy and argue that women were simply mimicking male behaviour, or shift the blame on to licensed grocers for supplying women with alcohol. The idea that women were worse drunks than men cast them as the weaker sex in terms of alcohol consumption and intoxication more broadly. Put simply, it was believed that men could handle their drink and women could not and to some extent this dictated the social rules of public and private drinking. Therefore the women who chose to drink alcohol, in spite of the social rules, were in some ways resisting the status quo.

\section{Notes}

1. House of Commons Parliamentary Papers (HCPP). 1877: c. 171: First Report of the Select Committee of the House of Lords on Intemperance: Question from Lord Aberdaire to John Jackson, Chief Constable of Sheffield.

2. HCPP. 1877: c. 171: First Report from the Select Committee of the House of Lords on Intemperance: Evidence of John Jackson, Chief Constable of Sheffield.

3. HCPP. 1877: c. 171: First Report from the Select Committee of the House of Lords on Intemperance: Evidence of John Jackson, Chief Constable of Sheffield.

4. HCPP. 1877: c. 171: First Report from the Select Committee of the House of Lords on Intemperance: Evidence of John Jackson, Chief Constable of Sheffield.

5. HCPP. 1877: c. 418: Third Report of the Select Committee of the House of Lords on Intemperance: Evidence of Reverend James Nugent.

6. HCPP. 1877: c. 418: Third Report of the Select Committee of the House of Lords on Intemperance: Evidence of Reverend James Nugent.

7. HCPP. 1877: c. 418: Third Report of the Select Committee of the House of Lords on Intemperance: Evidence of Reverend James Nugent.

8. HCPP. 1877: c. 418: Evidence of Reverend James Nugent.

9. HCPP. 1877: c. 271: Second Report of the Select Committee of the House of Lords on Intemperance: Evidence of John Alexander Bremner.

10. HCPP. 1877: c. 271: Evidence of John Alexander Bremner.

11. HCPP. 1877: c. 271: Evidence of John Alexander Bremner.

12. HCPP. 1877: c. 418: Third Report of the Select Committee of the House of Lords on Intemperance: Evidence of Reverend James Nugent: Question from the Bishop of Carlisle to Reverend Nugent.

13. HCPP. 1877: c. 271: Second Report of the Select Committee of the House of Lords on Intemperance: Evidence of Mr William Smith. 
14. HCPP. 1877: c. 271: Evidence of Mr William Smith.

15. HCPP. 1872: c. 242: Select Committee on Habitual Drunkards: Evidence of Dr Alexander Peddie.

16. Briggs A. 1985. Wine for Sale: Victoria Wine and the Liquor Trade 18601914: Chicago: University of Chicago Press: pp. 9-18.

17. HCPP. 1877: c. 418: Third Report of the Select Committee of the House of Lords on Intemperance: Evidence of Reverend David Howell.

18. HCPP. 1877: c. 271: Second Report of the Select Committee of the House of Lords on Intemperance: Evidence of Captain James Nicholls.

19. HCPP. 1878: c. 1941: Grocers Licenses (Scotland) Commission: Evidence of Duncan McLaren MP.

20. 'The Grocers License', The Lancet: Volume 110:2810: 7 July 1877: pp. 27-18.

21. HCPP. 1878: c. 1941: Grocers Licenses (Scotland) Commission: Evidence of Reverend William Turner.

22. HCPP. 1878: c. 1941: Grocers Licenses (Scotland) Commission: Evidence of Reverend William Turner.

23. 'Royal Commission on Licensed Grocers': The Glasgow Herald: 25 October 1877.

24. de Certeau M. 1984. The Practice of Everyday Life: Berkeley: University of California Press: p. xix.

Open Access This chapter is licensed under the terms of the Creative Commons Attribution 4.0 International License (http://creativecommons.org/licenses/ by $/ 4.0 /$ ), which permits use, sharing, adaptation, distribution and reproduction in any medium or format, as long as you give appropriate credit to the original author(s) and the source, provide a link to the Creative Commons license and indicate if changes were made.

The images or other third party material in this chapter are included in the chapter's Creative Commons license, unless indicated otherwise in a credit line to the material. If material is not included in the chapter's Creative Commons license and your intended use is not permitted by statutory regulation or exceeds the permitted use, you will need to obtain permission directly from the copyright holder.

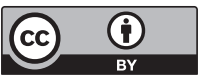

